\title{
Will firms consider a European optional instrument in contract law?
}

\author{
Gary Low
}

Published online: 1 November 2011

(C) The Author(s) 2011. This article is published with open access at Springerlink.com

\begin{abstract}
The diversity of contract laws is said by the Commission to discourage cross-border trade and hinder the development by SMEs of a pan-European commercial policy. An optional instrument containing both facilitative general contract rules and mandatory consumer protection rules, one of the solutions proposed by the Commission, is gaining rapid support from key stakeholders. Drawing from firms' own views on the problems of legal diversity, and insights from organisational science, this article sets out the circumstances in which firms will likely consider a European optional code. Results are mixed: some firms may consider it, while others may ignore it. Much depends the firm's aspirations (i.e. SMEs cannot be assumed as-yet to have pan-European aspirations), how the firm perceives the problems of legal diversity, and how it searches for and decides upon solutions. It would appear that a European optional instrument may not be as useful or widely considered as its proponents would like to believe.
\end{abstract}

Keywords Contract law $\cdot$ Harmonisation $\cdot$ Behavioural analysis

Jel Classification $\mathrm{K} 12 \cdot \mathrm{D} 03 \cdot \mathrm{F} 15$

\section{Introduction}

The European Commission (the Commission) has recently published a Green Paper ${ }^{1}$ for the reform of European contract law. This document marks the culmination of 10 years of the Commission's consultation with political, commercial and academic

\footnotetext{
1 Green Paper from the Commission on policy options for progress towards a European Contract Law for consumers and businesses, COM (2010) 348 final (hereinafter 'Green Paper on European contract law').
} 
stakeholders, and the start of the legislative process at the European level. One of the key reasons ${ }^{2}$ for the Commission's interest is that the very diversity of contract laws (hereinafter 'legal diversity') within the European Union (EU) is said to hinder the ability of firms to conduct cross-border commerce and adversely impacts consumer confidence. A range of solutions is presented, spanning the spectrum from hard law to soft law instruments, and toying with both mandatory and nonmandatory rules. Of these alternatives, the frontrunner appears to be that of an optional instrument-having garnered a respectable degree of support from a number of key stakeholders. ${ }^{3}$

In other words, an optional instrument is presented as the means to improve the functioning of the Internal Market by removing obstacles to cross-border trade allegedly caused by legal diversity, the latter in the form of 27 different national contract laws. Fundamentally, since these 27 national laws are themselves considered as the problem, will firms flock to an optional instrument to govern their cross-border transactions instead of one of these laws? This rumination can no longer be viewed as moot, especially in light of recent developments in the area. ${ }^{4}$

As one of the main beneficiaries ${ }^{5}$ of this reform, it is crucial to understand whether and how the firm perceives of legal diversity as a problem and an optional instrument as a solution in cross-border trade. In so doing, this article attempts to shed some light as to the appropriateness of introducing an optional instrument within European contract law.

This article proceeds in the following manner. In Sect. 2, the relevant background is set out, including what the Commission has identified as problematic of contract laws within the EU, along with the key features of an optional instrument. Drawing largely from Cyert and March's A Behavioral Theory of the Firm (BTF), Sect. 3 describes how firms crystallise aspirations, how they perform, and how they perceive and resolve problems. Section 4 draws from feedback given to the Commission from firms themselves regarding their views on cross-border trade and on what they perceive to be the benefits and burdens of legal diversity. These may, but sometimes do not, coincide with the Commission's position on the matter. These views are used as a starting point to construct how, generally, a firm makes decisions regarding choices of law governing cross-border contracts; and particularly, whether and when a European optional instrument is considered in the firm's decision-making process. The results appear dependent not only on the type of problem arising from the diversity of contract laws and the content of the optional instrument, but also the occasions when and manner in which firms choose laws. The resultant effect of an optional instrument is mixed: some firms may ignore it, though other may use it. Larger firms appear to benefit from its availability, rather than smaller firms. Section 5 concludes.

\footnotetext{
2 The other reason is to improve the coherence of the consumer acquis communaitaire.

3 See for instance the briefing notes to the 27.10.10 workshop for the European Parliament's Committee on Legal Affairs_- “An Optional Instrument for EU Contract Law”_available at http://www.europarl. europa.eu/webnp/cms/lang/en/pid/1483.

4 See Sect. 2.

5 The other beneficiary being the consumer-for a general discussion on the possible effects of legal diversity on consumer behaviour, see generally (Low 2010) and also (Sefton-Green 2011).
} 


\section{Legal diversity: perceived problems and solutions}

A European optional instrument appears to be the way forward ${ }^{6}$ in European contract law. It has the backing of the European Parliament, ${ }^{7}$ and has been mentioned in four recent and important policy papers-the Digital Agenda for Europe,${ }^{8}$ the Single Market Report, ${ }^{9}$ Europe 2020, ${ }^{10}$ and Project Europe 2030. ${ }^{11}$ All four call for the adoption of an 'optional 28th system' inter alia to help steer Europe's fragile economic recovery and complete the Internal Market. The 2010 Green Paper on the reform of European contract law ${ }^{12}$ reiterates the view (which is also suggested in a number of its predecessor policy papers $)^{13}$ that the divergences amongst the contract laws of the Member States negatively affect firms and consumers. ${ }^{14}$ The purpose of an optional instrument, if introduced, will thus be to strengthen the Internal Market by facilitating cross-border transactions and combat the problems caused by diversity. The next couple of passages sketch out how diversity of contract laws is alleged by the Commission to be problematic for crossborder trade, and, thereafter, how an optional instrument is intended to solve this problem.

\subsection{Perceived problems in European contract law}

Normatively, facilitative and mandatory contract rules serve different purposes. Facilitative rules can be in the form of either default rules (i.e. opt-out) or optional

\footnotetext{
${ }^{6}$ There are hints of dissent from some key quarters in a number of Member States. For instance, the House of Lords Subcommittee E is not persuaded to support any European measure (including an optional instrument) unless there is clear evidence that legal diversity impedes cross-border trade: see the summary of the subcommittee's 12th report on European Contract Law: the Draft Common Frame of Reference (19 May 2009).

${ }^{7}$ European Parliament resolution of 25 November 2009 on the Communication from the Commission to the European Parliament and the Council—An area of freedom, security and justice serving the citizenStockholm programme, 25 November 2009, P7_TA(2009)0090, especially paragraph 99.

${ }^{8}$ Communication from the Commission to the European Parliament, the Council, the European Economic and Social Committee and the Committee for the Regions on A Digital Agenda for Europe, COM (2010) 245 especially pp. 12-13.

${ }^{9}$ Mario Monti, A New Strategy for the Single Market-At the Service of Europe's Economy and Society, 9 May 2010, available at: http://ec.europa.eu/bepa/pdf/monti_report_final_10_05_2010_en.pdf [accessed 28 October 2010] especially pp. 93-94.

${ }^{10}$ Communication from the Commission, Europe 2020-A strategy for smart, sustainable and inclusive growth, COM (2010) 2020 especially p. 19.

${ }^{11}$ Project Europe 2030-Challenges and Opportunities, A report to the European Council by the Reflection Group on the Future of the EU 2030 at pg 41. Available at http://www.reflectiongroup.eu/ wp-content/uploads/2010/05/reflection_en_web.pdf (accessed 28 October 2010).

${ }^{12}$ Green Paper especially Sect. 3.

${ }^{13}$ See for instance the Communication from the Commission to the Council and the European Parliament on European Contract Law, COM (2001) 398 final. Also Communication from the Commission to the Council and the European Parliament on A More Coherent European Contract Law-An Action Plan, COM (2003) 68 final especially pp. 9-14.

${ }^{14}$ Divergence is said to add to unnecessary transaction costs and create legal uncertainty for firms, and contribute to a lack of confidence for consumers to take advantage of the Internal Market.
} 
rules (i.e. opt-in). To the extent that parties are permitted to and do in fact choose these rules, they exist to help organise parties' contractual relationship, whether domestic or otherwise. In the event parties omit to choose rules in particular circumstances, such rules (where applicable) operate as gap-fillers.

Mandatory rules, on the other hand, may be thought of as a paternalistic intervention in what is otherwise a largely private relationship. As the appellation 'mandatory' suggests, such rules cannot be contracted out of. As regards their functions, mandatory rules may be economic in nature (e.g. rules on fraud or duress to correct market failure) or advance specific interests (e.g. consumer protection rules) or espouse a specific moral view (e.g. the non-enforceability of contracts contra bono mores).

Despite the definition given (above), the term 'mandatory' is somewhat of a misnomer because it masks the fact that, depending on the type of rule and the kind of transaction, parties may be at liberty to avoid some of these rules. In the same way one may avoid a disfavoured facilitative rule, the mandatory rules of a governing law may simply be avoided by choosing a different law to govern the contract. $^{15}$

The case is radically different when one of the parties to the contract is a consumer. Both the Rome Convention ${ }^{16}$ and Rome Regulation ${ }^{17}$ dictate that the mandatory rules of a consumer's habitual residence apply regardless of the parties' choice of law. These include consumer protection rules ${ }^{18}$ as well as rules on life insurance (Basedow 2003:57).

One may thus distinguish between facilitative rules and mandatory rules of the law of the contract, on the one hand, and (if applicable) the mandatory rules of the law of the consumer's habitual residence, on the other. The basis of the distinction is the freedom to choose (or, more precisely, the freedom to avoid). Needless to say, the laws that govern a contract contain a mix of both facilitative and mandatory rules, and whether the parties can determine the precise mix of the two is in large part dependent on whether the contract at hand is commercial or consumer in nature.

The result of recent policy discussions instigated by the Commission seems to be that the contract laws currently in existence at EU level or MS level are inadequate or insufficient to facilitate both commercial (B2B) and consumer (B2C) transactions (and how can they, since they themselves are alleged to have caused the problem?). As regards facilitative rules (largely in B2B contracts), an unequal bargaining power leads to small and medium sized enterprises (SMEs) being forced to adopt whatever national law their larger counterparty so wishes. In other words, the freedom to choose a set of facilitative rules or avoid a set of mandatory rules is a freedom that is in practice the reserve of larger firms. SMEs in such a situation are not only saddled

\footnotetext{
15 Case C-339/89 Alsthom Atlantique SA v Compagnie de construction mecanique Sulzer SA [1991] ECR I-107.

16 Art 5, 1980 Rome Convention on the law applicable to contractual obligations.

17 Art 6, Regulation 593/2008 of the European Parliament and of the Council of 17 June 2008 on the law applicable to contractual obligations OJ L-177/6.

18 Joined Cases C 585/08 Peter Pammer v Reederei Karl Schluter GmbH \& Co KG and C-144/09 Hotel Alpenhof GesmbH v Oliver Heller (07 December 2010).
} 
with information-related costs of uncovering what the law insisted upon by their contracting party stipulates, they are also unable to coordinate a 'uniform commercial policy across the Union, preventing these businesses from grasping opportunities in the internal market'. ${ }^{19}$

As regards mandatory rules, the use of minimum harmonisation and the practice of 'gold-plating' ${ }^{20}$ especially in the area of consumer protection, means that firms are faced information and compliance-related ${ }^{21}$ costs multiplied by the number of jurisdictions they wish to trade in. Since these are incurred by all firms, regardless of size, that wish to conduct cross-border consumer transactions, they are blamed for discouraging many firms from selling to consumers in foreign markets. ${ }^{22}$

\subsection{An optional instrument to the identified problems}

The Commission proposes that, inter alia, a European optional instrument could be a panacea for the two above-mentioned problems. For firms and especially SMEs, this opens the possibility for them to operate throughout the EU with a single set of rules. As regards consumer contracts, the optional instrument 'would have to affect the application of mandatory provisions, including those on consumer protection' and 'would need to offer a manifestly high level of consumer protection" ${ }^{\text {23 }}$ allowing those who choose the optional instrument to avoid the costs of complying with a divergent range of national consumer protection regimes.

Based on the above discussion, a number of key points can be made. The Commission clearly perceives a legal (cf. mandatory rules) and practical (cf. facilitative rules) problem with legal diversity, corresponding with the rules and freedom of choice regarding consumer and commercial contracts. Furthermore, it assumes that SMEs aspire to adopt a pan-European commercial policy, and that an optional instrument is able to overcome their weaker bargaining position viz. their larger counterparts. If these points are accurate, then firms ought to opt for it to govern their cross-border transactions especially when faced with either or both these problems. Whether this expectation is realistic is resolved in the next two sections.

\section{A behavioral theory of the firm (BTF)}

In 1963, almost 50 years ago, Cyert and March published their pathbreaking $A$ Behavioral Theory of the Firm (Cyert and March 1963). Building on Simon's work on bounded rationality, ${ }^{24}$ the book challenged the conventional way of looking at

\footnotetext{
${ }^{19}$ Green Paper on European contract law, page 7 (emphasising the importance of the role played by SMEs in the Internal Market).

20 The adoption of standards higher than that of the minimum.

21 This is since consumer protection rules are typically mandatory in nature.

22 Green Paper on European contract law, p. 5.

23 Green Paper on the reform of European contract law, pp. 9-10.

24 See for instance Simon $(1955,1956)$.
} 
the firm. The firm, according to Cyert and March, is not a rational monolithic structure. It is, instead, an amalgamation of bounded rational actors engaged in a number of fundamental processes that influence the firm's behaviour. The features of the behavioural firm have been used to explain organisational behaviour and decisions across countries and sectors, and its explanatory power is one of the main reasons why the theory persists to this day. ${ }^{25}$ This is also the reason why the behavioural theory is used in this article to explain to how firms may decide on choices of law in cross-border trade-a question that is largely unexplored within existing literature on European contract law. ${ }^{26}$

The salient features of the behavioural firm are as follows: (1) the firm is a political firm and its goals are reached through negotiation and mediation; (2) the firm translates its goals into an aspiration level and evaluates its performance against this level; (3) the firm's unutilised resources are known as 'slack', which it can inter alia deploy to improve its performance or intensify its search for solutions to pressing problems; (4) the type and intensity of search is dependent on, and relative to, its current performance and aspiration level. These points are developed in the following passages.

\subsection{Goals, aspirations and performance}

The scarcity of resources means that no organisation can pursue everything-choices will have to be made. This is done with the help of goals regarding what and what not to pursue. Every organisation thus starts with defining the goals that are key to its mission. Organisations start by defining abstract goals (organisational goals) and thereafter operationalise them (i.e. operational goals). ${ }^{27} \mathrm{~A}$ firm, as a species of organisation, also has goals to define. These goals can theoretically be anything, though, for a commercial entity, a number of obvious ones might be profitability, sales and production. Finnish telephony giant Nokia's mission statement, for instance, is 'connecting people' and to 'become the leading provider of mobile solutions'. This is operationalised by leveraging on 'a portfolio of outstanding devices (...) couple them with smart services, integrated via an intuitive and seamless user experience (...) differentiate these solutions offerings based on our in-depth consumer understanding, with a strong focus on social location' ${ }^{28}$ For Bristol-based SME Orthos Orthobiologics, its mission is to 'excel through innovation and to grow by exceeding the expectation of our customers'. 29

\footnotetext{
25 For a review, see Argote and Greve (2007) and Augier and March (2008).

26 A number of papers presented at the annual SECOLA conference in Leuven in January 2011 touched on a wide and important range of issues on the theme of choice in contract law, though none dealt specifically with the question of how either firms or consumers choose governing laws or contract terms: see for example Sefton-Green (2011) and Cartwright (2011).

27 There are many different types of goals, and it is useful to distinguish between at least two of themorganisational goals and operation goals. Organisational goals tend to be abstract in nature, and can be found in the firm's charter or constitution or shareholders' agreement and in annual reports. Operation goals are the practical, concretised translation of organisational goals. For a full treatment of an organisation's goals, see Perrow (1961).

28 http://www.nokia.com/about-nokia/company/vision-and-strategy.

29 http://www.orthos.com/index.html.
} 
In defining the firms's goals, according to Cyert and March (1963:26-43), it ought to be borne in mind that the firm is a coalition of individuals, each with different individual goals and objectives. The need for coordination and the possibility for conflict are very real. Protection of the environment and profitability, for example, do not necessarily fit hand in glove. On the one hand, shareholders may desire profit maximisation, while on the other, managers may be motivated to pursue firm growth or to maintain a pleasant (rather than pressured) working environment. Due in large part to the need to resolve these conflicting interests, the firm engages in a constant process of negotiating and mediating in order to arrive at a set of agreed organisational and operational goals to pursue and their order of priority.

In Schneider's words (Schneider 1992:1053), the firm has to negotiate for each goal 'the smallest outcome that would be deemed satisfactory by the decision maker, given the current choice situation'. This is also known as the aspiration level. What a firm aspires to in the future is informed by what has happened in its past and by its present environment. In organizational science, these are termed 'historical' and 'social' aspirations, the combination of which comprises the firm's aspiration level in totality (Cyert and March 1963:39-41, 162-163). Returning to the case of Nokia, it has set for itself a high level of aspiration-to be 'the leading provider of mobile solutions'.

Historical aspiration indicates that decision makers use past performance as a yardstick of what is desirable and possible, and measure future performance accordingly (Lant et al. 1992; Greve 1998). This means that aspirations adapt to performance-if the firm is underperforming, decision-makers are liable to revise their aspirations downwards, and vice versa (Bromiley 1991; Fiegenbaum and Thomas 1995). As to social aspiration, this is the product of decision makers looking to rivals firms who have similar production methods or products or markets. Rival performance is monitored closely, and own performance is measured against those of rivals (Clark and Montgomery 1999; Reger and Huff 1993). One may draw a parallel to social comparison situations within which individuals measure themselves against others with similar salient attributes (Festinger 1954). It is important to note that in using its past experience and measuring itself against its peers, the firm moderates its expectations to what it thinks is realistically achievable.

At this stage, the firm has defined goals and has set for itself a level of performance to which it aspires. Two further comments can be made- the first on the relationship between goals and aspiration levels, and the second on the relationship between performance and aspiration levels.

First, compromises are apparent in goals and aspiration levels set. Let us return to the example of Orthos Orthobiologics: 'we constantly review and challenge everything we do so as to ensure that we are delivering the highest possible standards whilst maintaining the commercial objectives of our company'. ${ }^{30}$ That the firm must balance or compromise between its various goals (in this case, high

\footnotetext{
30 http://www.orthos.com/about_us.html (emphasis added).
} 
quality as well as profitability) entails it being satisfied so long as its performance meets a certain minimum threshold.

Second, decision makers routinely peg the firm's current performance to its aspiration level. Using the aspiration level as a reference point allows the firm to determine whether it is performing well enough to achieve its goals. This thus constitutes a feedback mechanism and this is an important feature of the firm's decision-making process. It allows the firm to decide whether it has set an appropriate aspiration level, whether enough resources are being deployed to pursue its goals, whether there are search processes that may need to be initiated or terminated to align performance with aspiration, and whether there is a need to revise aspiration levels to reflect what the firm can realistically achieve.

\subsection{Problemistic search}

According to the BTF, the 'problemistic search' (March and Simon 1958; Cyert and March 1963:121) is one of the core features of a search. As the phrase suggests, this is a search that is 'stimulated by a problem (usually a rather specific one) and is directed toward finding a solution to that problem' (Cyert and March 1963:169). In general, problemistic searches are triggered whenever the firm perceives that it performing below its aspiration level. Firms under competitive pressure have been known to look to innovating or upgrading their product lines or processes to improve performance (Greve and Taylor 2000; Greve 2003), or change everyday firm practices otherwise entrenched by inertia or risk aversion (McDermott and O’Connor 2002).

Recall that the behavioural theory is a political account of mediating the conflicting interests of firm personalities, giving rise to behaviour, which seeks to assuage these interests. Problemistic search is a product of these satisficing factors. It results in managers looking for a 'quick fix' solution-i.e. solutions are sought within the local or neighbouring environment of the problem. Localised search reflects decision-makers' beliefs 'that a cause will be found "near" its effect and that a new solution will be found "near" an old one' (Cyert and March 1963:170). Thus, for instance, when a problem regarding manufacturing arose, solutions were sought within the physical environs of the plant floor. This is despite the fact that if a more global approach was used, they might have discovered the root problem to lie instead with product design (MacDuffie 1997). ${ }^{31}$ This somewhat parochial (as opposed to global) attitude determines where and how far (or near) the search net is cast, though, arguably not necessarily in a good way: it hinders firms from seeking better alternatives 'further' from the problem or current alternative. Having said that, if a suitable alternative cannot be found using localised search, firms use more complex and distant search, extending the search net further outwards (Cyert and March 1963:171).

\footnotetext{
31 Three problems (water leakage, electrical faults, paint processes) were identified for study at the factories of three major car manufacturers. These three were specifically chosen because they were common problems with potentially multiple causes, both in design or process. In a number of factories, design engineers labeled them as localized process problems and thus declined to work with plant engineers to solve them.
} 
Having said that, there may be idiosyncratic situations' (Ahuja and Katila 2004). when firms are immediately forced to move beyond their comfort zones to search for solutions. Ahuja and Katila (2004:888) examined the search patterns of multinational American chemicals firms in the area of research and development. They found that in markets where technologies were already well exploited, firms in the area of innovation foray into the area of scientific knowledge 'to acquire fresh raw material'. For an example within the EU, take Bristol-based Orthos Orthobiologics. The firm competes in a market where 'technology has advanced at all but exponential speed' (Goetz and Aminoff 1998:48) and which thus forces competitors to move beyond their comfort zones. With an eye to sourcing new technologies, it contacted the Commission-backed Enterprise Europe Network (EEN) to 'help them identify opportunities to work with universities across Europe', ${ }^{32}$ eventually tapping into academic research generated by the Polytechnic University of Catalonia in Spain to commercially exploit their bone regeneration products. $^{33}$

According to Ahuja and Katila (2004:888, 890), '[f]irms operating across different national markets are likely to be faced with different sets of local problems. These may range from local preferences on specific products or services, manufacturing processes or availability of material. In addition, one might add different regulatory burdens. These may necessitate product and/or process adaptation by the firm (Ghemawat 2001). Geographically expanding its product market and facing these similar sets of problems causes firms to be driven to expand international research to address local opportunities and problems.'

While expanding its geographic product market generates problems, it also presents opportunities. Amongst other things, presence in a foreign market 'increases the firm's awareness and appreciation of locally developed technology, regional science and technological networks, and of the potentially lower costs for research activities in foreign sites' (Ahuja and Katila 2004:890).

Localisation is but one of two characteristics of problemistic search. The second has to do with decision-makers' past experiences with searching. Their past experience determines the manner in which information is sought. Decision-makers often look back to previous problems to see whether the same solutions can be applied, or to look for analogies or similarities to apply the past to present problems or solutions (Cyert and March 1963:174).

Finally, given that firms have to search for alternatives, it stands to reason that there must be a rule that determines when searching ought to stop. Simply put, alternatives are evaluated in sequential order, usually each in turn of the time of discovery. This is largely because of the firms' limited processing and search capabilities (Tversky 1972; Cyert and March 1963:134). Once a solution is found which meets the firm's aspiration level, searching ought to terminate.

\footnotetext{
32 MTB Europe, 'Orthos licenses bone regeneration technology from Catalonia University' (8 June 2010), accessed at http://www.mtbeurope.info/news/2010/1006016.htm on 25 November 2010.

33 http://www.enterprise-europe-network.ec.europa.eu/success-stories/bones-great-deal.
} 


\subsection{Slack and slack-induced search}

Much like any other organisation, the firm has resources at its disposal to pursue its goals. Unutilised resources-present whenever less resources are required to achieve the firm's aspirations-are what Cyert and March (1963:40-44) term 'organisational slack'. Organisational slack can take the form of administrative resource, like facilities for research and development or the time set aside for employee development. Slack can also be financial, and in the form of cash reserve or financial instruments, or when firm borrowing is less than its full potential.

Slack can be tapped into when the need arises. Slack is in this way important because it is the means by which performance is able to adapt to aspirations. If the firm underperforms, it is able to utilise slack to intensify the search for solutions. The result is a decrease in slack, increase in performance, and a lowering of the aspiration level. Vice versa, if the firm is performing well, search deceases, slack increases, and the aspiration level rises (March 1994:30-33).

Also, firms with a greater amount of spare time and resource have less need for strict monitoring of performance levels and more opportunities for experimentation. Underperformance is thus not the only reason for search. When the firm has excess resources, decision-makers 'are free to pursue idiosyncratic preferences'. This type of search is usually called 'slack search' or success-induced search', because a firm usually has more slack at its disposal when it is performing well than if it was underperforming. Put differently, problemistic search is initiated when the firm must, whereas slack search is conducted when the firm can.

The timing of slack search is not its only difference with problemistic search, but it does explain why the nature of the searches is different. Slack searches are not conducted under conditions of adversity. As such, firm control and coordination are loosened. Decision makers can take longer-term views and also experiment. Searches are thus 'less tightly linked to key objectives and are less likely to be careful (Cyert and March 1963:32),' but because they are not tied to solving specific problems, they may tend to be more innovative.

\section{Choosing a European optional instrument}

It was generally described, in the preceding section, how a firm defines its aspirations and gears up its performance. Problems are defined relative to performance and aspirations. Searches and the manner in which they are conducted are dependent on whether they are commenced when the is underperforming or not. In the following passages, these insights from BTF are applied to the context of European contract law in order to flesh out how, it at all, a European optional instrument may be considered for use in cross-border trade.

\subsection{Goals, aspirations and cross-border trade}

Much of a firm's behaviour is dictated by the goals and aspiration levels it sets for itself. Important goals for the firm would probably include an element of profit, but 
profit is more likely than not to be one of a number of goals competing for a firm's limited resource. Importantly, whether conducting cross-border trade is (or is a means to) a goal of the firm is a matter reserved for that firm to decide.

Needless to say, goals and aspirations change, but it is beyond the scope of this article to determine what the goals are of the over 20 million firms that operate in the EU, and whether they aspire to provide goods and services to all half-a-billion consumers in the Internal Market. It may readily be assumed that the conduct of cross-border trade is a matter that firms may or may not be interested in or currently aspire to. Some may have pan-European or global ambitions; others, perhaps, may geographically limit their desires to neighbouring countries; still others may prefer to concentrate on their home market only. If firms wish to trade across borders, it remains a strategic decision on their part whom they wish to trade with, and therefore a strategic - and often bilateral or multilateral-decision regarding which laws to govern their transactions. ${ }^{34}$

Take the example of European supermarket chains, which are likely to be larger firms. Brands like the French Carrefour or Belgium's Makro dot the globe (though they do not compete in every continent), the German Lidl concentrates on a large number of constituents in the Internal Market and the Nordic countries but not the Baltic states, the Austrian bauMax runs stores in seven Central and Eastern Europe countries as well as Turkey, whereas the Luxembourgoise market leader Cactus is virtually domestic focussed.

Associations representing SMEs have indicated to the Commission that such firms do not harbour plans for an EU-wide commercial policy, and not because legal diversity prevents them from doing so. As the European Association of Craft, Small and Medium-Sized Enterprises (UEAPME) asserted as early as 2001,

SMEs usually target a concrete foreign market and try to adapt to it, without aiming to develop an EU-wide strategy. In this context, they need of course some information on the relevant market, sector and national legislation, which has a cost, but this should not be overestimated. ${ }^{35}$

A casual glance at the Commission's grooming efforts of SMEs is also consistent with the view that growth for these firms may be incremental rather than radicalsmaller firms branch out beyond their domestic markets to one or two foreign markets, rather than adopt a broad Europe-wide strategy. Through the EEN, ten-man French firm Westline which markets automation devices ventured first to Poland. Likewise, Vleeschouwer, an entrepreneur who marketed an anti-reflux bed in Belgian pharmacies started out by selling to German hospitals. ${ }^{36}$

Given that firms may have different goals and aspirations, and given that these may change over time, it is important to realise that the changes to the state of European contract law brought about by a European optional instrument are likely

\footnotetext{
34 See [4] of the response of the Confederation of British Industries (CBI) to the 2001 Communication: http://ec.europa.eu/consumers/cons_int/safe_shop/fair_bus_pract/cont_law/comments/2.1.6.pdf.

35 Emphasis added. UEAPME response to the 2001 Communication at http://ec.europa.eu/ consumers/cons_int/safe_shop/fair_bus_pract/cont_law/comments/2.5.4.pdf.

36 See "Driving a cross-border deal" at http://www.enterprise-europe-network.ec.europa.eu/successstories/driving-cross-border-deal and "Infant business grows across borders" at http://www.enterpriseeurope-network.ec.europa.eu/success-stories/infant-business-grows-across-borders.
} 
to affect different firms differently. If, for instance, Cactus has no wish to venture beyond Luxembourg, the perceived relevance of an optional instrument to domestic-oriented firms like Cactus is likely to be negligible. This is also the view of the Hoge Raad voor de Zelfstandigen en de KMO (the Belgian association for SMEs and the self-employed), which is in favour of an optional instrument because this will allow domestic-facing firms the possibility of avoiding it. ${ }^{37}$

For firms which do or at the very least wish to trade across borders, but do as yet not have pan-European ambitions, the utility derived by a person like Vleeschouwer or a ten-man firm like Westline from using a European optional instrument may be relatively limited. One would do well to bear in mind UEAPME's caveat that one ought not to overestimate the costs of legal diversity. The problem an optional instrument purports to solve is only as large as the number of jurisdictions the firm(s) in question are (or desire to be) active in.

\subsection{Problemistic search: mixed results}

Next, assuming that goals are determined and aspiration levels are set, whether and the manner in which an optional instrument are evaluated are contingent on the firm's performance relative to its aspiration level-i.e. problemistic and slack searches. We will consider each type of search in seriatim.

The first to be considered is problemistic search: that is, searches initiated when firms perform below their level of aspiration. Before we commence the discussion on problemistic searches in the context of contract law, however, it ought to be mentioned that the mere fact that a firm is underperforming does not mean that a search on alternatives and consequences in the domain of contract law is initiated. Whether it does so is obviously dependent on the nature of the problem associated with the firm's underperformance.

If there is no link between the governing law and the underperformance, there will be no search for information on contract laws. The low productivity of workers in Westline's French automation device factory, for instance, probably has nothing to do with whether a cross-border contract of sale of those same devices is governed by French or Polish contract law. On a related note, the legal problems a firm faces in cross-border trade may have nothing to do at all with general contract law or consumer law - these being the subject matter of a European optional code-but, for instance, with insolvency laws or property laws to the extent these apply by virtue of the conflicts of law rules and notwithstanding the choice of governing law. ${ }^{38}$ Additionally, even if the set of contract rules used might be unsatisfactory,

\footnotetext{
37 "Die oplossing laat aan de ondernemingen en de consumenten, die niet actief willen zijn buiten de landsgrenzen, toe om hun contracten verder te laten regelen door hun nationaal recht waarvan zij de draagwijdte kennen. Op deze wijze genieten zij ook van het voordeel dat er geen nutteloze bijkomende lasten worden opgelegd aan die ondernemingen die geen internationale activiteiten ontplooien." - The Belgian Council for the Self-Employed and SMEs-response to the 2010 Green Paper (in Dutch) at http://www.hrzkmo.fgov.be/Portals/hrzkmo/nl/Advies\%20per\%20datum/2010/N\%20651\%20EU\%20 contractenrecht.pdf.

38 See the response of the International Swaps and Derivatives Association (ISDA) to the 2003 Action Plan. (http://ec.europa.eu/consumers/cons_int/safe_shop/fair_bus_pract/cont_law/stakeholders/2-20.pdf).
} 
that in and of itself does not trigger a search or indicate the firm will seek to change the law it uses unless those rules cause or contribute to the firm's problems. ${ }^{39}$ In the same way, if a law currently used is experienced as satisfactory, the firm will have little impetus to switch to a purportedly better alternative In a nutshell, in all the above-mentioned situations, the firm has little rhyme or reason to question the value of using this set of laws if nothing from the performance of the underlying transaction gives cause for it to do so. ${ }^{40}$

Moving on to situations where the rules in force are problematic, a number of observations may be stated.

Despite the problems that may arise with legal rules, changing contractual terms or choosing different laws are not the only solutions. One must not come away with the pre-conceived notion that law is always central to the transaction. Socio-legal studies have shown that in some trading communities, resort to law is excluded altogether (Ellickson 1992; Bernstein 1992). In others, it is a mere handmaiden to extralegal social norms and customs. Transactions often occur in the shadow of the law, and not in its light (Macaulay 1963; Beale and Dugdale 1975; Bernstein 2001; Macaulay 2003). The specific terms giving rise to conflict, regardless of whether they are expressly chosen or mandatorily applied, may be irrelevant if the aggrieved party chooses not to rely on it, or if the parties adopt a consensual arrangement that skirts around the problematic term (Low 2010:294-295, 297-298).

Having said that, any number of contract-law related situations may arise. These may leave the firm's performance viz. its aspiration level unaffected, or may contribute to underperformance. Disputes as regards the express terms of the contract, or the default or mandatory rules in force, are all matters which potentially hinder the firm in attaining its aspiration level. Certain facilitative terms may insufficiently or unsatisfactorily regulate the incentives for performance or the sanctions for breach. Some mandatory rules may interfere with the freedom to structure these incentives or sanctions, or may expose firms to greater risk than they have an appetite for.

Not all of them, though, will trigger a search for a different governing law, let alone the selection of a European optional code. This is so partly because of the nature of the problem, but also due to the way in which information is searched for and alternatives are chosen. Problemistic search patterns limit the scope of search to within the locale of the problem. The firm does not ask 'what law is best suited for this transaction' but poses the narrower 'which rule neutralises this particular problem'.

There is as yet scant ${ }^{41}$ evidence on problemistic searches in context of choices of law, and therefore also of how firms might define what the locales of the problems faced or alternatives sought, but one might surmise the following conduct.

\footnotetext{
39 This is except where the firm engages in slack-induced searches.

40 See however, the discussion on slack searches, although even in those cases, the firm is likely to be resistant to innovate if it is already performing at or above its aspiration level.

41 A search was conducted on 20.01.11 on a collection of journals on databases like Westlaw and Lexis Nexis using the terms 'choice of law', 'contract law' and 'problemistic search', and which yielded a 'nil' return.
} 
The firm initiates its search processes and utilises its administrative and financial slack. Given that problemistic searches tend to be (at least initially) localised, it is likely that solutions are first sought from within the confines of the pre-existing set of laws rather than to search for other suitable legal systems. This means that instead of looking to switch their governing law or jurisdiction clause, firms may for instance look at how other industry associations or rivals draft their contractual terms to redraft or add to their own in order to arrest the problem at hand. The typical Anglo-American commercial contract became voluminous by the drafting-in of contingencies not previously anticipated, rather than an immediate knee-jerk reaction to switch from English or New York law. Orgalime, the association for mechanical, electrical, electronic and metal industries across the EU, has indicated that insofar as firms retain the freedom to do so, problems are resolved through standard form contracting and a high quality of draughtsmanship. ${ }^{42}$

If this is so, then the switching of governing laws, let alone consideration of a European optional instrument, does not even arise. That firms address in such a manner problems arising from non-mandatory rules might explain why a number of pan-European trade associations regard the harmonisation of facilitative contract law as irrelevant, but note the need to harmonise divergent mandatory rules. ${ }^{43}$

If, for whatever reason, searches beyond one's legal system are necessary, a search and evaluation of other laws is initiated. Localised search patterns suggest that firms may start looking for answers in territorially adjacent countries or related legal traditions. A firm using Dutch law might start with Belgian or German law as possible alternatives. A firm using English law might look to any number of common law jurisdictions like New York or Singapore. Furthermore, decisionmakers may consider alternatives they may not otherwise have, as a result of exposure or experience in the foreign markets they operate. Thus a firm like Orthos Orthobiologics, that might be expected to use English law, might by virtue of its ties with the Polytechnic University of Catalonia, consider Spanish law. On a related note, a newly minted European optional instrument will obviously not (yet) be actively used in the EU. Decision-makers in firms will not have experienced using it and will not be familiar with its use (Cartwright 2011). An optional instrument may not be thought of immediately as an alternative, or appear ahead in the queue in which alternatives are sequentially evaluated.

Given such a search pattern, in a European Union of more than two dozen domestic contract laws and optional codes, a number of possibly viable intraEuropean alternatives are systematically omitted from even consideration. This may

\footnotetext{
42 Response by Orgalime (representing over 100,000 mostly SMEs across a number of member states and industries) to the 2001 Communication (http://ec.europa.eu/consumers/cons_int/safe_shop/fair_ bus_pract/cont_law/comments/2.1.7.pdf).

43 Response by Orgalime stating that "differences in the non-mandatory background law is not a major problem (...) This is mainly due to the long established practice of using general contract conditions to limit the effect of such differences (...) Even if there existed a uniform non-mandatory law this practice of using general conditions would continue". UEAPME, an association also of SMEs, offered a similar response: "According to the experiences of our members-national professional associations representing SMEs-, the differences in contract law among the different Member states do not constitute a significant problem for cross-border transactions (...) the situation is different when talking about ... mandatory rules". (http://ec.europa.eu/consumers/cons_int/safe_shop/fair_bus_pract/cont_law/comments/2.5.4.pdf).
} 
entail the exclusion of a European optional instrument. This is compounded by way in which alternatives are evaluated-sequentially and not globally. Thus the first satisfactory alternative is chosen, ending both the search and decision-making process. These factors may result in a lower opt-in rate for a European optional instrument than might otherwise be expected opt-in rate.

The situation is similar even if the problem arises from the application of a mandatory rule, which firms cannot avoid simply by engaging in a drafting exercise. In a typical B2B contract, firms may find recourse through a different set of laws (cf. Alsthom Atlantique). ${ }^{44}$ As with the above, however, localised search patterns may limit the chances of consideration and use of a European optional instrument. However, if whatever alternative firms end up with is considered by them to be satisfactory or suffices for the purposes of dealing with the problem that has arisen, then the diversity of contract laws cannot be said to be a bane of cross-border transactions.

At this juncture, it is important to highlight to the reader the limitations of using a framework that describes the internal processes of the firm. While it allows us to predict the circumstances when an optional instrument may be considered, it says nothing about whether it will in fact be chosen (i.e. how negotiations on choice of law take place as between the contracting parties). It also sheds very little light on how an opt-in instrument will impact the uneven bargaining position of SMEs viz. larger firms.

In $\mathrm{B} 2 \mathrm{C}$ transactions, divergent insurance or consumer protection rules are unavoidable if a firm wishes to trade in any one member state. The problem is multiplied by the number of national markets that a firm wishes to trade in. Let us not, however, overstate the issue as far as smaller firms are concerned. The point has been mentioned previously, but it is worth reiterating that SMEs do not necessarily wish to trade across the entirety of the Internal Market, and "need of course some information on the relevant market, sector and national legislation, which has a cost, but this should not be overestimated'. 45

The magnitude of the problem caused by the divergence of mandatory laws is directly related to the number of member states that a firm does or wants to trade in. This might suggest why the International Chamber of Commerce, representing a host of larger firms including firms based outside the EU, voiced its support for an optional instrument in order to reach the 'whole Internal Market in a cost efficient manner' ${ }^{46}$ This is also in line with Ahuja and Katila's observation that as firms venture into increasing numbers of foreign markets and are faced with different local problems, they are more motivated to find international solutions to these

\footnotetext{
${ }^{44}$ French law was the law governing the contract in that case. Under French law, the warranty for latent defects had been elevated to the status of a mandatory rule. The case went before the ECJ on the issue of whether such a rule infringed the free movement of goods. The Court held that such a rule did not infringe the free movement provisions since parties could easily have avoided it by selecting a different governing law.

45 Emphasis added. See UEAPME response.

46 ICC Comments to the 2001 Communication. Specifically, the ICC supports the harmonisation of European contract law but emphasises the importance of preserving party autonomy.
} 
problems. ${ }^{47}$ Larger firms tend to have both the ambition to think and the resources to act in terms of Europe-wide or global commercial strategies.

To the (mainly larger) firms who perceive divergent laws to be a problem, the present alternatives provide no solution. A European optional instrument would by definition be the only alternative. That is, if it contains mandatory rules on consumer protection which displace or replace their domestic counterparts, and if the costs of complying with differing national consumer protection standards is greater than the costs of complying with the standard set out in the optional instrument. If it does not solve the problem of legal diversity, ${ }^{48}$ or the results of a cost-benefit analysis are negative, ${ }^{49}$ or if the problem is solved, for instance, through the passage of the draft Directive on Consumer Rights, ${ }^{50}$ then firms have no reason to consider a European optional instrument as a viable alternative. As with B2B contracts, it is the larger firms who appear to have a prima facie incentive to select an optional instrument.

At a level of generality, the above analysis applies to firms engaged in e-commerce as it does for brick-and-mortar firms. This is because many of the factors which may contribute to decisions regarding cross-border trade apply to both types of firms. Such decisions are, in turn, likely to be dependent on the nature of the good sold or service peddled. Some of the factors affecting trade of real goods and services may not be as relevant regarding purely digital goods or services like digitised music or e-books or webhosting traded on the digital market. The fact that copyright regimes are enforced along national lines, for instance, is said to discourage firms from offering a range of products online, but need not discourage them from setting up a physical shop in another member state. ${ }^{51}$ For both online and offline markets, diversity of contract laws may play a role in strategic decisions regarding cross-border trade-for instance, the centrality of the law as regards insurance contracts cuts across the mode of sale.

But that is not all there is to it. It has already been mentioned that there are also other legal issues, and practical or economic factors. Besides the diversity of consumer law, one also notes the diversity of taxation systems (particularly VAT regimes), and the differing ease of enforcement of contractual rights. Already mentioned are the problems caused by the diversity of insolvency law (e.g. ease of recovery for bankruptcy) and property law which compounds the risks underlying transactions related to transfer or retention of ownership. Non-law factors may include logistics, demand for products or services, availability of credit and political risks. The list goes on.

\footnotetext{
${ }^{47}$ See above at Sect. 3.2.

${ }^{48}$ For instance, if a European optional instrument does not offer a harmonised standard of consumer protection rules.

49 This might include transition costs (retraining of staff and redrafting of contracts), and will depend on the level of consumer protection in the optional instrument viz the pre-existing levels in the 27 Member States.

${ }^{50}$ Proposal for a Directive of the European Parliament and of the Council on consumer rights COM (2008) 614 final. This proposal seeks to bring coherence and uniformity to a number of directives in the consumer acquis.

${ }^{51}$ Commission Staff Working Document, "Report on cross-border e-commerce in the EU", SEC (2009) 283 final.
} 
This last comment brings to the fore the fact that a Europeanised contract law is but one element in integrating the EU's 27 national markets and encouraging firms and consumers to trade across all 27 national borders-which is a reason why in 1985 Lord Cockfield may have thought a further 300 measures cutting across different aspects of the economy were necessary to complete the Internal Market, ${ }^{52}$ and why in late October 2010, Commissioner Barnier revealed a further 50 proposals in his Single Market Act. ${ }^{53}$ It is not unreasonable to say that the diversity of contract laws may in some situations be a clog in the cross-border wheel of trade. One must, however, also take care to avoid thinking of contract law as the entire wheel itself rather than a mere $\operatorname{cog}$.

\subsection{Slack-induced searches}

Accepting that there is a dearth of research on on slack searches in the domain of choices of law, the following may nevertheless be ventured.

Slack searches may occur when firms are performing at or above their aspiration level. Decision-makers are not under competitive pressures or controls, and are relatively able and free to explore and innovate. Their opportunity and ability to do so are dependent on the amount of slack the firm has. In response to the availability of slack, the firm may adjust its aspiration level upwards. Decision-makers may search for ways in which to improve the efficiency with which they conduct crossborder trade, or may seek to expand their presence in foreign markets. Hesselink (2010), for instance, gives anecdotal evidence of a large insurer thinking global instead of local. ${ }^{54}$ If so, a firm might seek to discard its depacage of a legalcommercial policy, and a European optional instrument might be amongst the alternatives considered.

Whether such an instrument suits the needs of firms is a question that has to be considered. In turn, that depends on the kinds of transactions firms enter into, relative to what and how the optional instrument regulates these matters. Even if such an instrument regulates consumer protection satisfactorily, the fact that other fields of mandatory rules are not touched may mitigate against its overall utility to a number of firms engaged in a variety of transactions. Furthermore, as with the conclusion arrived at with regard to problemistic searches, the framework does not allow us to further predict whether firms will ultimately opt for an optional instrument in their contractual negotiations.

Having said that, one finds it hard to deny the benefit of such an instrument as regards the innumerable, straightforward, bilateral, offline and online consumer transactions. If that is the case, an optional instrument's utility would be primarily as regards $\mathrm{B} 2 \mathrm{C}$ rather than $\mathrm{B} 2 \mathrm{~B}$ contracts-its main attraction being the

\footnotetext{
52 Completing the Internal Market, COM (85) 310 final.

53 Communication from the Commission to the European Parliament, the Council, the European Parliament, the Economic and Social Committee and the Committee of the Regions, Towards a Single Market Act, COM (2010) 608 final.

54 A recent briefing paper to the European Parliament suggested, citing anecdotal evidence from a single large insurer, that a number of firms might prefer a European optional instrument in an effort to present themselves to consumers as being post-national.
} 
harmonisation of unavoidable consumer protection rules rather than that of being a single rule capable of replacing any number of national contract rules for a host of cross-border transactions.

\section{Recapitulation and concluding remarks}

This article sets out to demonstrate whether and how firms may react to a European optional instrument, if introduced. Legal diversity is alleged to be a problem in both consumer and commercial contracts, and is a particular hindrance to SMEs developing an EU-wide commercial policy. A European optional instrument purports to solve these problems by offering a set of neutral Europe-wide facilitative rules coupled with a set of mandatory consumer protection rules which displace or replace existing national ones.

Based on anecdotal evidence from the field as well as BFT's framework on how firms behave, the results of what show that some firms may opt for it, and others will not even consider it. Extracting from the discussion on goal-setting and on problemistic and slack searches, it becomes apparent that demand for a European optional instrument for firms depends on a number of factors.

First, whether firms have as a goal or aspiration to operate across the EU. As comments from associations representing SMEs show, this cannot simply be assumed. Some firms operate domestically without any cross-border aspirations, and others develop incrementally. Where and how to expand are commercially-oriented decisions, rather than legal ones. To this category of firms, the optional instrument is likely an irrelevant solution to an irrelevant problem.

Second, depending on the nature of the problem, but also the nature of the search process, firms may not even consider a European optional instrument. Localised searches suggest that the first port of call for firms is to work within pre-existing contractual structures and governing laws (for instance by re-drafting or adding contractual terms). If the need to search for an alternative governing law arises, the firm looks first to similar legal traditions or neighbouring jurisdictions. It may also consider legal systems it has already been exposed to in its transactions with foreign markets or actors. At the point in time of its introduction, a European optional instrument does not feature in any of the above categories. While it is true that the firm widens its search if a suitable alternative is not found, it is also true that the firm considers alternatives sequentially and ends its search once a suitable alternative is found. Thus the search might end even before the search net is widened to include alternatives like the European optional instrument.

Third, even if firms do not perceive a need to switch viz. their current performance, they may do so as an outcome of slack-induced searches. The likelihood of a European optional instrument being adopted as a result of such searches remains questionable, not the least because the precise scope and nature of the instrument is as-yet unknown, and also because it remains in the short run an unfamiliar set of rules to its potential users.

Fourth, and this is related to a number of previously discussed points, the European optional instrument appears to be the only solution with regards to the 
problem of diversity of consumer protection laws. Thus in B2C transactions, firms may be enthusiastic about such an instrument. Not all though. Such enthusiasm is however directly proportional to the number of jurisdiction a firm trades in. For SMEs which trade across a minority of member states, they may not see the need to opt for the instrument. As mentioned, it is also dependent on whether firms see a benefit in adopting the level of consumer protection set out in the instrument.

Fifth, importantly, while the foregoing analysis describes the instances when an optional instrument might be considered, it does not predict what impact such an instrument will have on the inferior bargaining position occupied by SMEs. That, in turn, may affect the likelihood of an optional instrument being chosen to govern the transaction in question. In this way, even if SMEs do not see the need for an optional instrument, it may nevertheless be used if their larger trading partner insists upon its use.

Firm behaviour viz. a European optional instrument is important on several different levels. Their behaviour (i.e. whether they opt for or ignore the instrument) is directly relevant to whether such an instrument solves the problems caused by an alleged diversity of contract laws within the EU, and also speaks as to the instrument's effectiveness. Through a discussion on aspiration and performance levels, this article has attempted to show that the problems of legal diversity may be restricted in magnitude. While an optional instrument may make a positive contribution in those instances where it does exist, its utility is framed by the limits of how firms perceive that selfsame problem (i.e. the extent of legal diversity). Without clearer evidence of firm behaviour in this domain, it is of course difficult to state with accuracy whether an optional instrument will proliferate across the Internal Market. However, insights regarding aspiration levels and firm searches ought at least to give pause to those who may, in their enthusiasm, embellish the extent to which an optional instrument can contribute towards facilitating cross border trade and establishing the Internal Market.

Acknowledgments I take this opportunity to express my appreciation to the Hague Institute for the Internationalisation of Law (HiiL) for financial assistance, and to Cornell Law School, where research for part of this paper was undertaken. Any views and all errors herein are exclusively my own.

Open Access This article is distributed under the terms of the Creative Commons Attribution Noncommercial License which permits any noncommercial use, distribution, and reproduction in any medium, provided the original author(s) and source are credited.

\section{References}

Ahuja, G., \& Katila, R. (2004). Where do resources come from? The role of idiosyncratic situations. Strategic Management Journal, 25(8/9), 887-907.

Argote, L., \& Greve, H. R. (2007). Behavioral theory of the firm: 40 years and counting: Introduction and impact. Organization Science, 18(3), 337-349.

Augier, M., \& March, J. G. (2008). A retrospective look at a behavioral theory of the firm. Journal of Economic Behavior \& Organization, 66(1), 1-6.

Basedow, J. (2003). Insurance contract law as part of an optional European contract act. ERA Forum, 4(2), 56-65. 
Beale, H., \& Dugdale, T. (1975). Contracts between businessmen: Planning and the use of contractual remedies. British Journal of Law and Society, 2(1), 45-60.

Bernstein, L. E. (1992). Opting out of the legal system: Extralegal contractual relations in the diamond industry. Journal of Legal Studies, 21(1), 115-157.

Bernstein, L. E. (2001). Private commercial law in the cotton industry: Creating cooperation through rules, norms, and institutions. Available at http://www.ssrn.com.

Bromiley, P. (1991). Testing a causal model of corporate risk taking and performance. Academy of Management Journal, 34(1), 37-59.

Cartwright, J. (2011). Choice is good. Really? Annual conference of the society of European contract law in Leuven.

Clark, H. C., \& Montgomery, D. B. (1999). Managerial identification of competitors. Journal of Marketing, 63(3), 67-83.

Cyert, R. M., \& March, J. G. (1963). A behavioral theory of the firm. Englewood Cliffs, NJ: Prentice-Hall.

Ellickson, R. (1992). Order without law: How neighbours settle disputes. Cambridge, Massachusetts: Harvard University Press.

Festinger, L. (1954). A theory of social comparison processes. Human Relations, 7(2), 117-140.

Fiegenbaum, A., \& Thomas, H. (1995). Strategic groups as reference groups: Theory, modeling and empirical examination of industry and competitive strategy. Strategic Management Journal, 16(6), 461-476.

Ghemawat, P. (2001). Distance still matters. The hard reality of global expansion. Harvard Business Review, 79(8), 137-147.

Goetz, C. G., \& Aminoff, M. J. (1998). Handbook of clinical neurology: Systemic diseases part II. Amsterdam: Elsevier.

Greve, H. R. (1998). Performance, aspirations, and risky organizational change. Administrative Science Quarterly, 43(1), 58-86.

Greve, H. R. (2003). A behavioral theory of R\&D theory expenditures and innovations: Evidence from shipbuilding. Academy of Management Journal, 46(6), 685-702.

Greve, H. R., \& Taylor, A. (2000). Innovations as catalysts for organizational change: Shifts in organizational cognition and search. Administrative Science Quarterly, 45(1), 54-80.

Hesselink, M. (2010). An optional instrument on EU contract law: Could it increase legal certainty and foster cross border trade? Briefing note for the European Parliament's Committee on legal affairs.

Lant, T. K., Miliken, F. J., \& Batra, B. (1992). The role of managerial learning and interpretation in strategic persistence and reorientation: An empirical exploration. Strategic Management Journal, 13(8), 585-608.

Low, G. (2010). The Ir(relevance) of harmonisation and legal diversity to european contract law-A perspective from psychology. European Review of Private Law, 17(2), 288-289.

Macaulay, S. (1963). Non-contractual relations in business: A preliminary study. American Sociological Review, 28(1), 55-67.

Macaulay, S. (2003). The real deal and the paper deal. Modern Law Review, 66, 44-79.

MacDuffie, J. P. (1997). The road to 'root cause': Shop floor problem solving at three automotive assembly plants. Management Science, 43(4), 479-502.

March, J. G. (1994). A primer on decision making. New York: The Free Press.

March, J. G., \& Simon, H. A. (1958). Organisations. New York: Wiley.

McDermott, C. M., \& O'Connor, G. C. (2002). Managing radical innovation: An overview of emergent strategy issues. Journal of Product Innovation Management, 19(6), 424-438.

Perrow, C. (1961). The analysis of goals in complex organizations. American Sociological Review, 26(6), $854-866$.

Reger, R. K., \& Huff, A. S. (1993). Strategic groups: A cognitive perspective. Strategic Management Journal, 14(2), 103-123.

Schneider, S. L. (1992). Framing and conflict: Aspiration level contingency, the status quo, and current theories of risky choice. Journal of Experimental Psychology. Learning, Memory, and Cognition, 18(5), 1040-1057.

Sefton-Green, R. (2011). Why more is less. Annual conference of the society of European contract law in Leuven.

Simon, H. A. (1955). A behavioral model of rational choice. The Quarterly Journal of Economics, 69(1), 99-118.

Simon, H. A. (1956). Rational choice and the structure of the environment. Psychological Science Review, 63(2), 129-138.

Tversky, A. (1972). Elimination by aspects: A theory of choice. Psychological Review, 79(4), 281-299. 